\title{
THE HYPOGLOSSAL COMPLEX OF VERTEBRATES
}

\author{
JOHN WALTER BARNARD \\ Departments of Anatomy of the University of Michigan, Ann Arbor, and \\ Georgetown University, Washington, D. C.
}

TWENTY-FOUR FIGURES

CONTENTS

Introduction and material $\ldots \ldots \ldots \ldots \ldots \ldots \ldots \ldots \ldots \ldots \ldots \ldots, 489$

Description of the hypoglossal complex $\ldots \ldots \ldots \ldots \ldots \ldots \ldots \ldots \ldots \ldots \ldots \ldots, 489$

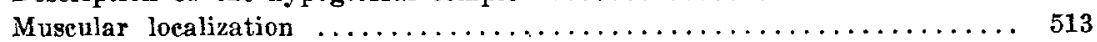

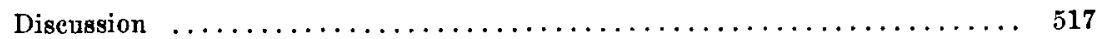

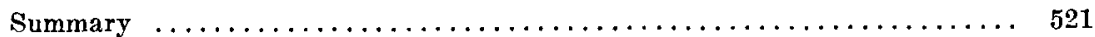

INTRODUCTION AND MATERIAL

The present work is a study of the hypoglossal nucleus of vertebrates. In this account an attempt has been made to determine, as far as possible, the significance of the various nuclear subgroupings, and to relate their description with others in the literature. The normal material used in describing the hypoglossal nucleus and its root is part of the Huber Neurological Collection of the Department of Anatomy of the University of Michigan and consists of both cell and fiber preparations of the frog, several turtles, several lizards, the alligator, four birds, the opossum, the shrew, the bat, the mouse, the rat, the rabbit, the sheep, the dog, the cat, the macaque monkey and man. I wish to take this opportunity expressing my appreciation for the assistance and kindly criticism given to me by Doctor Elizabeth Crosby.

DESCRIPTION OF THE HYPOGLOSSAL COMPLEX

$$
\text { Frog }
$$

The frog is the lowest vertebrate to have a discrete hypoglossal nucleus and a muscular tongue. In Rana catesbiana 
some of the cephalic cells of the cervical motor column have migrated to the dorsolateral aspect of the medial longitudinal fasciculus (fig. 1). These large, coarsely granulated, multipolar neurons with long dendrites spreading out into the lateral field, make up the dorsomedial nucleus as described by Black ('17). The group is more or less divisible into a dorsal and a ventral part, although rostrally it is made up of only one column, this latter being continuous with the dorsocaudal nucleus. The caudal half of the main hypoglossal nucleus overlaps the forward end of the ventral horn motor column (fig. 1).

The neuraxes of the hypoglossal cells leave the brain stem as three rootlets, which as they pass caudalward are joined by a small dorsal root. As Fürbringer (1897) and Gaupp (1899) have pointed out the hypoglossal nerve leaves the neural canal between the first and second spinal vertebrae, making it the second cervical nerve. There is a small ganglion attached to it as it goes through the intervertebral foramen. After passing lateral to the sympathetic trunk, with which no fibers are exchanged, it gives off the following branches; (1) a single bundle to the muscles of the dorsum of the neck, (2) a series of three fascicles to the lateral muscles that attach to the otic capsule, (3) two descending branches to the ventral neck musculature, (4) terminal twigs to the hyoglossal and genioglossal muscles.

The intramedullary fiber connections of the hypoglossal nucleus consist of many fascicles from the reticular gray ventrally and ventrolaterally, from the visceral sensory area dorsolaterally and from the medial longitudinal fasciculus. The dendrites of the main hypoglossal nucleus go to the lateral reticular area and the nucleus of the descending trigeminal root.

No accessory nuclear groups are associated with the hypoglossal nucleus other than the general inferior reticular cells which lie ventral and ventrolateral to the main nucleus. 


\section{Reptiles}

The relations of the hypoglossal complex are quite variable in reptiles. Addens ('33) found two hypoglossal nuclei completely detached from the ventral horn motor column in Caiman sclerops, whereas many reptiles such as Chelone, Varanus and Boa have no specialized nucleus (Ariëns Kappers, '11, '12) other than a poorly delimited portion of the cephalic cells of the ventral horn gray.

Turtles. In the newly hatched Graptemys pseudographica the hypoglossal nucleus is the cephalic end the anterior horn column (fig. 2). No adult material is available for study but it appears likely that the relations in the adult Graptemys would resemble more closely those found in other turtles.

Other turtles studied, Pseudemys elegans, Emys melageris, Chelhydra serpentina (fig. 3) and Chrysemys marginata (fig. 4), are all similar to one another. In Chrysemys the caudal limit of the hypoglossal nucleus is determined by following the root fibers toward their cells of origin. Slightly behind the calamus scriptorius the nucleus becomes split into two parts, a dorsal or main hypoglossal nucleus and a ventral or spinal portion. Occasional large motor neurons, lying between the two columns, link them into a single unit. The main

\section{ABBREVIATIONS}

c. c., central canal

desc. r. $N$. V., descending trigeminal root

d. nue. XII, dorsal hypoglossal nucleus dors. lat. nue. XII, dorsolateral division of hypoglossal nucleus

dors.nuc. $X$, dorsal vagal nucleus

f. sol., fasciculus solitarius

inf. olive, inferior olive

lat. ret. gray, lateral retieular gray med, nuc. XII, medial division of hypoglossal nucleus

m. 1. f., medial longitudinal fasieulus nuc. interc., nucleus intercalatus nue. desc. r. $N$. V., nucleus of the descending trigeminal root nuc. Roller, nucleus of Roller

nuc. $X$, vagal nucleus

nuc. XII, hypoglossal nucleus

nuc. $X I$, accessory nucleus

N. XII, hypoglossal nerve

$N$. $X$, vagus nerve

raphé nuc. XII, raphé division of hypoglossal nucleus

ret.gray, reticular gray

vent. lat. nue. XII, ventrolateral division of hypoglossal nucleus

v. nuc. XII, ventral hypoglossal nucleus vent. nuc. XII, ventral division of hypoglossal nucleus v. IV, fourth ventricle 

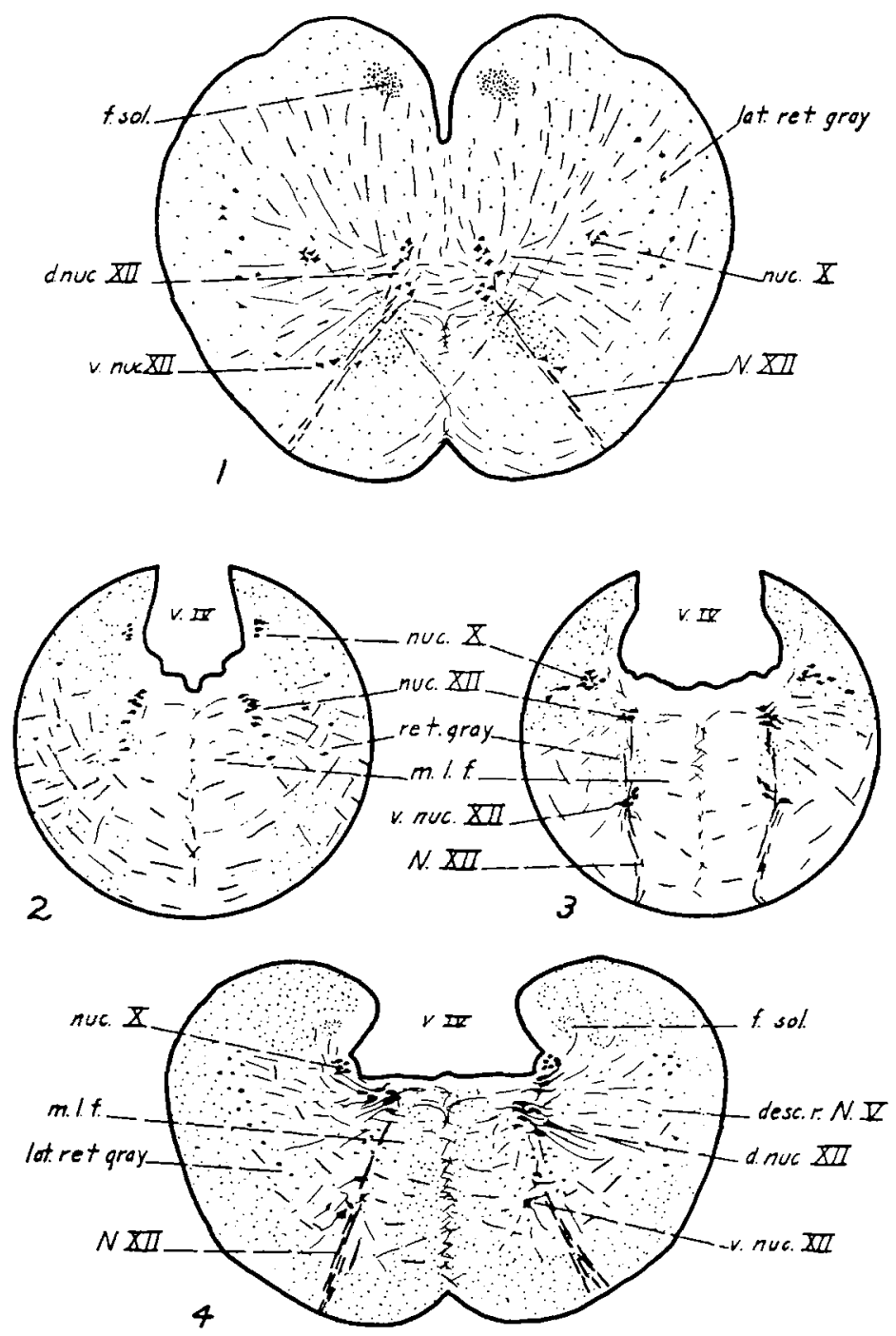

Fig. 1 A transverse section through the bypoglossal nucleus of the frog, Rana catesbiana. Toluidin blue. $\times 25$.

Fig. 2 Central part of a transverse seetion through the hypoglossal nucleus of the turtle, Graptemys pseudographiea. Toluidin blue. $\times 20$.

Fig. 3 Central part of a transverse section through the hypoglossal nucleus of the turtle, Chelhydra serpentina. Toluidin blue. $\times 20$.

Fig. 4 A transverse section through the hypoglossal nuclens of the turtle, Chrysemys marginata. Toluidin blue. $\times 20$. 
hypoglossal nucleus runs almost as far forward as does the dorsal vagal nucleus. The cells are arranged in clusters of which there are about 25 to a side. It splits such that the more dorsal cells are tilted dorsolaterally with their dendrites coming into close relationship with the visceral motor area, whereas the dendrites of the ventral cells spread toward the lateral reticular gray and the nucleus of the descending trigeminal root. As described by Tuge ('32) the reticular elements consist of the small cells lying between the dorsal and ventral hypoglossal nuclei.

The neuraxes of the hypoglossal cells gather into eleven or twelve fascicles, the rostral seven of which come only from the dorsal hypoglossal nucleus. These latter consolidate into the first hypoglossal root whereas the caudal four or five fascicles form the second or caudal hypoglossal root. Each root leaves the skull through its own foramen. The first branch of the caudal root, which is joined by a twig from the first cervical nerve, goes to the dorsal musculature of the neck as Willard ('15) found in Anolis. Farther ventrolaterally much of the caudal root and a small fascicle of the cephalic root break up into muscular branches which go to the lateral neck musculature. The remaining fibers of each root pass caudoventralward as a single hypoglossal nerve which gives off a number of small branches to the infrahyoid musculature before entering and innervating the tongue muscles.

The fiber connections of the hypoglossal nucleus of these turtles are much like those in the frog. The slight increase in complexity and quantity found is in direct proportion to the general increases of the turtle brain.

Snakes and Lizards. In the copperhead (Agkistrodon mokasen, fig. 5), the watersnake (Natrix fasciatus, fig. 7), the python (fig. 8) and the horned toad (Phrynosoma suspectum, fig. 6) the hypoglossal nucleus lies dorsorostral to the anterior motor column. Only in the python is there a gap between the two motor groups such that for a short distance there are scarcely any somatic efferent cells present in the transverse fields. In all of these forms the hypoglossal nucleus, in which 
no subdivisions can be found, is separated laterally from the medial longitudinal fasciculus by a large mass of small reticular cells. These latter are continuous with similar cells of the spinal cord. Nakamura ('30) believed that they form the homologue of Roller's nucleus.

Alligator. In the American alligator (fig. 9) the hypoglossal nucleus is the dorsofrontal continuation of the spinal cord gray. The cells of the chief or dorsal nucleus, lying on the dorsolateral aspect of the medial longitudinal fasciculus, spread their dendrites laterally and ventrolaterally. There is a suggestion of a splitting of the chief nucleus into dorsal and ventral parts that is reminiscent of the conditions found in the frog and in other reptiles and is, perhaps, a foreshadowing of the clearer separation found in birds and in mammals. The neuraxes of the motor cells leave the brain stem as sixteen fasicles, the rostral eight of which come from the dorsal nucleus only. They coalesce into three rootlets which then leave the skull through two foramina, the caudal foramen containing two rootlets.

\section{Birds}

The hypoglossal nucleus of birds has specializations that are far greater than those found in the corresponding nucleus of reptiles. These special features, however, in keeping with peculiar functional and morphological adaptations of the bird, are quite different from those shown by mammals.

Duck. In Anas boscas (fig. 10) the cephalic end of the ventral horn motor column is divided into a dorsal and ventral part, the former of which gives rise to hypoglossal fibers as has been described by Brandis (1893), Ariëns Kappers ('12), Black ('22) and Sanders ('29). In addition to these extensions of the ventral horn there is a dorsal hypoglossal nucleus which has been termed the nucleus intermedius of X-XII by Ariëns Kappers who believed that it contributes fibers to the vagal as well as to the hypoglossal roots. Kosaka and Yagita ('03) on the basis of experimental work, could find no evidence for this last. In the available material 

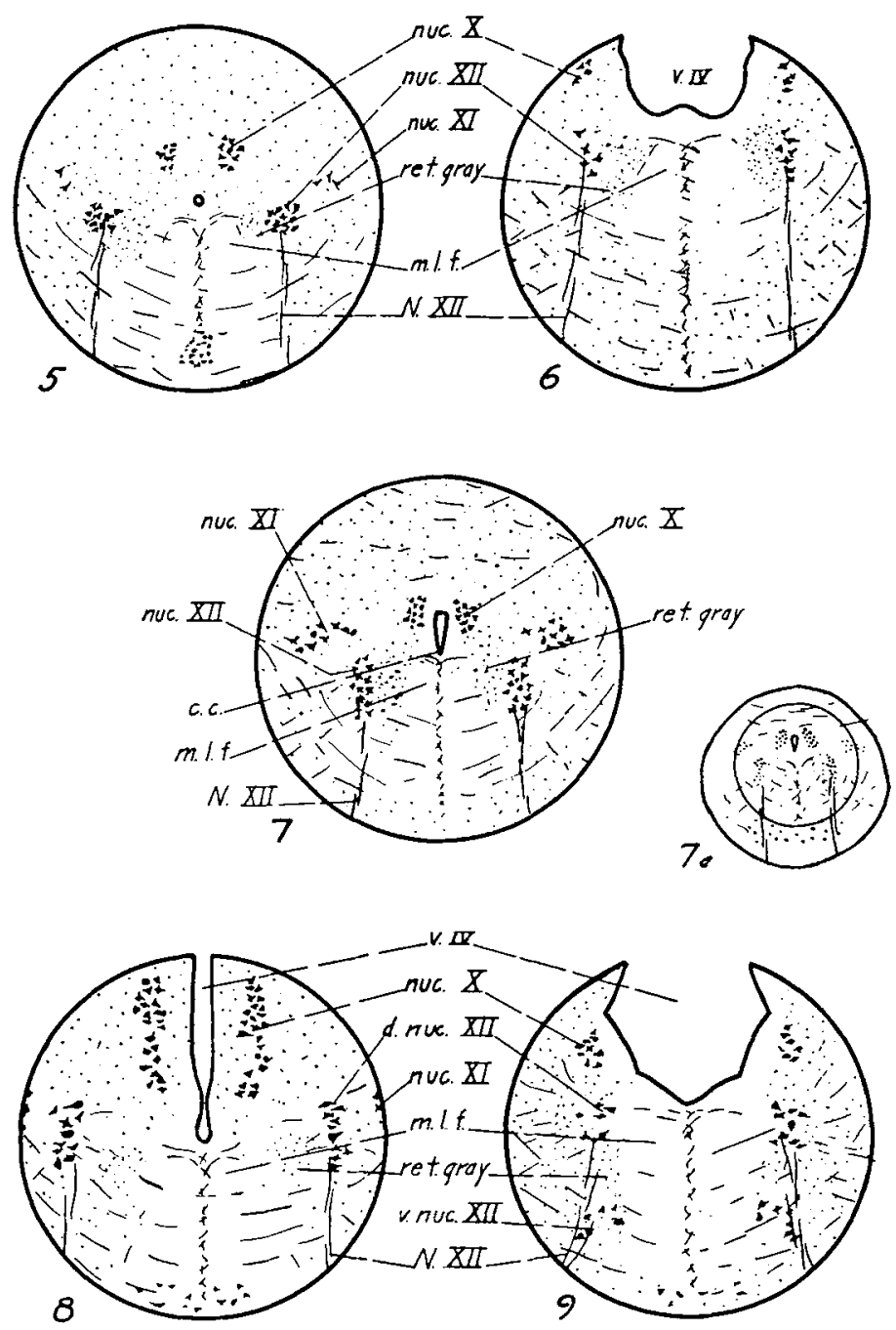

Fig. 5 Central part of a transverse section through the hypoglossal nucleus of the copperhead snake, Agkistrodon mokasen. Toluidin blue. $\times 30$.

Fig. 6 Central part of a transverse section through the hypoglossal nucleus of the horned toad, Phrynosoma suspectum. Toluidin blue. $\times 30$.

Fig. 7 Central part of a transverse section through the hypoglossal nucleus of the watersnake, Natrix fasciatus. Toluidin blue. $\times 30$.

Fig. 8 Central part of a transverse section through the hypoglossal nucleus of the python. Toluidin blue. $\times 30$.

Fig. 9 Central part of a transverse section through the hypoglossal nucleus of the alligator, Alligator mississippiensis. Toluidin blue. $\times 25$. 
the cells are all of the large, multipolar, somatic efferent type. At midlevels (fig. 10) the dorsal nucleus is divided into a dorsal and ventral portion but more rostrally into a dorsal and a lateral group.

Chicken. The hypoglossal nucleus of Gallus domesticus (fig. 11) is similar to that of the duck. The ventral horn motor column continues forward into the brain stem as the ventral hypoglossal nucleus, dividing into a medial and a lateral part much as described by Addens ('33) for the chick and by Beceari ('22) for the Italian sparrow. The dorsal hypoglossal nucleus, which extends as far caudalward as does the dorsal vagal nucleus, lies on the dorsolateral aspect of the medial longitudinal fasciculus, separated by an appreciable space from the ventral horn gray. At midlevels (fig. 11) the nucleus is divided into a dorsomedial and a ventrolateral part.

On the ventral, medial and dorsal aspects of the dorsal hypoglossal nucleus there are small reticular cells, those lying dorsally having the same abundant fiber connections with the hypoglossal and vagal nuclei as does the nucleus intercalatus of mammalian forms.

In excellent silver preparations no hypoglossal cells can be seen sending their neuraxes out along the vagal rootlets, which is in agreement with the findings of Addens ('33) for the chick.

The fiber connections of the hypoglossal nucleus are mainly, short internuclear fibers from the surrounding homolateral reticular gray, from the contralateral periventricular gray, from the medial longitudinal fasciculus, from the lateral reticular nucleus and the nucleus of the descending trigeminal root. Hypoglossal dendrites spread out, as in reptiles, laterally and ventrolaterally.

Dove. In Columbia livia (fig. 13) the ventral horn motor column divides into a dorsomedial and a ventrolateral group, the former running forward as the ventral hypoglossal nucleus, which divides into a medial and a lateral subgroup. The dorsal or main hypoglossal nucleus, which lies very close to the vagal nucleus, is divisible into a medial and a lateral 
group, this latter part assuming a more dorsal position at rostral levels.

The reticular elements associated with the hypoglossal nucleus are specializations of the periventricular gray found on the dorsal, medial and ventral aspects of the nucleus (fig. 13). The connections of these groups are diffuse. The hypoglossal root fibers arise from both the dorsal and ventral hypoglossal nuclei.

The fiber connections of the hypoglossal nucleus are similar to those found in the chicken. Many fibers from the nucleus of the fasciculus solitarius pass to the midline through the nucleus acting merely as fibers of passage (Barnard, '36).

Sparrow. In Passer domesticus (fig. 12) the ventral hypoglossal nucleus is like that of the dove. The dorsal nucleus is circular in outline at caudal levels but more rostrally is drawn out ventrolaterally into a diffuse oval. Sanders ('29) has pointed that this group is more or less continuous with the ventrolateral nucleus of Ariëns Kappers ('20) and of Black ('22). As described by Beccari ('22) the dorsal nucleus may be divided into a dorsomedial $(\alpha)$ and a ventrolateral $(\beta)$ part. His claim that the nucleus is continuous with the spinal accessory nucleus caudally is not borne out in the available material. Volker ('08) and Edgeworth ('35) have traced the embryology of the craniocervical muscle (a somatic muscle that develops in birds to replace functionally the non-appearing, branchiomeric cucullaris muscle) to occipital myotomes. Their work is in support of the contention of Beccari ('22) that the muscle supplied by the spinal accessory muscle is somatic in origin. The work of Edgeworth ('35) indicates that although this may be so in birds it is probably not so in other vertebrates as Addens ('33) would imply. The reticular elements around the hypoglossal nucleus of the sparrow differ in no fundamental way from those in the other birds examined.

The root fibers of the hypoglossal nucleus come from both the dorsal and ventral hypoglossal nucleus. Brandis (1893), Ariëns Kappers ('20), Sanders ('29) and Addens ('33) have found, in one bird or another, that the dorsal hypoglossal 

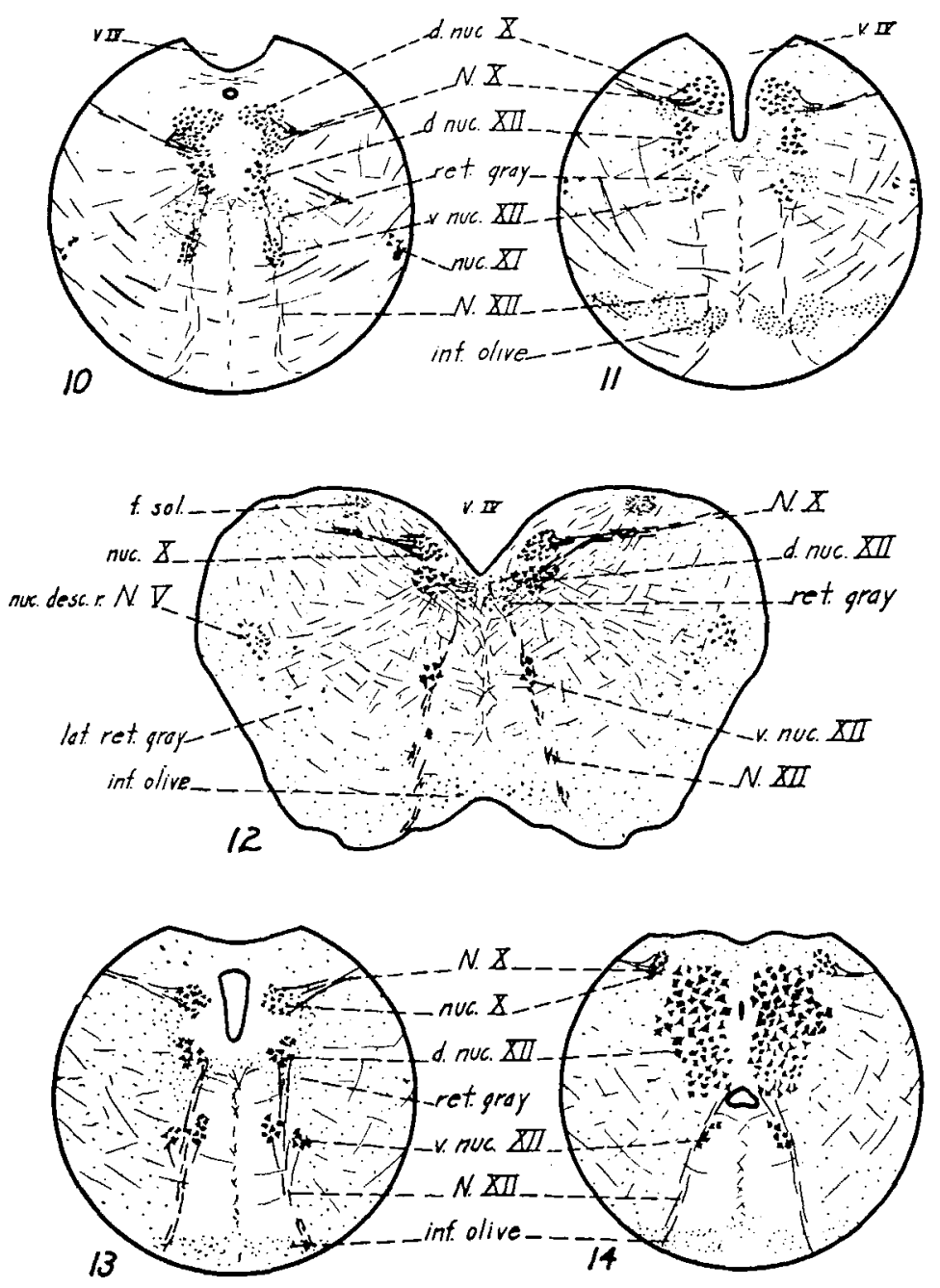

Fig. 10 Central part of a transverse section through the hypoglossal nucleus of the domestic duck. Toluidin blue. $\times 15$.

Fig. 11 Central part of a transverse section through the hypoglossal nucleus of the chicken. Toluidin blue. $\times 15$.

Fig. 12 A transverse section through the hypoglossal nucleus of the sparrow, Proser domesticus. Chrome silver. $\times 15$.

Fig. 13 Central part of a traneverse section through the hypoglossal nucleus of the dove, Columbia livia. Toluidin blue. $\times 15$.

Fig. 14 Central part of a transverse section through the hypoglossal nucleus of the parrakeet, Conuropsis carolinensis. Toluidin blue. $\times 15$. 
nucleus contains some cells the neuraxes of which leave the brain stem with the vagal rootlets. Sanders ('29) believed this to be so in Passer domesticus whereas Beccari ('22) could not find any such fibers in Passer italiana. In the available Passer domesticus silver material fascicles of vagal root fibers pass ventromedially into the dorsolateral corner of the hypoglossal nucleus but the individual fibers cannot be brought into relation with the cells of the nucleus either as neuraxes or dendrites nor can they be traced out of the nucleus. Only experimental or fortunate Golgi material would enable one to determine what these fibers are. Study of the cell material shows that the hypoglossal cells are all of the large somatic efferent type which would dispose one to regard the vagal fibers entering the nucleus either as crossing vagal neuraxes (see Addens '34) or as dendrites of sensory cells. The fiber connections of the hypoglossal nucleus are similar to those found in other birds.

Parrakeet. The bypoglossal nucleus of Conuropsis carolinensis (fig. 14) is almost entirely dorsal in position, the cephalic end of the ventral horn motor column extending but little into its levels. The nucleus is large, agreeing with the great muscularity of the tongue of this form. It may be subdivided into a ventral portion with smaller more densely staining cells and a dorsal part.

\section{Mammals}

The relations between the root and its nucleus was an early problem. Duval (1876), Koch (1888), van Gehuchten (1897), Vincenzi ('03) and Ramón y Cajal ('09) decided that there were no crossed root fibers and later experimental work has borne them out. Ariëns Kappers ('11, '20) studied the phylogenetic shifts of the nucleus. Ramón y Cajal supplied the neurobiotactic cause for these shifts by describing the internal connections of the sensory nerves of the tongue with the hypoglossal nucleus. Subdivisions within the hypoglossal nucleus were recognized by Deiters (1865) and Duval (1876). 
Attempts to describe these divisions accurately have been made by Ziehen ('03) in man, by Stuurman ('16, '16a) in the mouse and in the anteater, by Ariëns Kappers ('20) in the $\mathrm{dog}$, in the anteater and in Tamandua, by Beccari ('22) in the mouse, by Luna ('25) in the bat and by Barnard ('37) in various mammals.

Opossum. By mammalian standards the hypoglossal nucleus of Didelphis virginiana (fig. 15) is poorly differentiated. At the caudal limit of the nucleus a few motor neurons establish continuity with the ventral horn column of the spinal cord. Internally the nucleus is divisible into a dorsolateral and a ventromedial part as has been reported by Voris and Hoerr ('32). The latter portion may be further subdivided into a medial, a ventrolateral and a ventral portion. The medial group, the cells of which are spindle-shaped with their long axes pointed toward the midline, is found only in the rostral half of the hypoglossal nucleus. Caudally this medial group is replaced by the ventrolateral column. The ventral division, which is found in the middle third of the hypoglossal nucleus, is very small but may be identified by the great size of its cells as they lie among the outgoing root fibers. The dorsolateral nucleus, which extends throughout the rostral four-fifths of the hypoglossal complex, shows no subdivisions such as are found in other mammals.

A nucleus intercalatus and a nucleus of Roller are found at forward levels of the hypoglossal nucleus (fig. 15), the cells of Roller lying in among and lateral to the outgoing hypoglossal root fibers but not contributing to them. The nucleus intercalatus, which is interposed between the hypoglossal and the dorsal vagal nuclei, cannot be clearly delimited at its front end from the medial vestibular nucleus.

The fiber connections of the hypoglossal nucleus are similar to those found in lower forms. The lateral reticular gray and the nucleus of the descending trigeminal root send in many neuraxes which ramify throughout the nucleus. The nucleus of Roller and the nucleus intercalatus have numerous connections with the main nucleus. DuBois ('29) in the opos- 
sum and Kimmel ('40) in the rabbit found vagal rootlets entering the nucleus intercalatus. This is suggested in the Weigert stained, opossum material available for study. The visceral afferent gray medial to the fasciculus solitarius sends neuraxes to the hypoglossal nucleus with other arcuates that are passing to the midline. The medial longitudinal fasciculus contributes fibers to the hypogossal cell mass and, as the cortico-bulbar system probably reaches this nucleus it does so among these latter neuraxes. Dendrites of the hypoglossal nucleus spread lateralward and ventrolateralward making possible many connections with tracts from higher centers. At rostral levels of the nucleus there are strong commissural connections between the two hypoglossal nuclei.

Shrew. The hypoglossal nucleus of Blarina brevicauda (fig. 16) has a short, undifferentiated caudal end in which no subgroups are found. Farther forward it splits into a midline, a medial and a ventrolateral column, the first of which extends to the rostral tip of the nucleus. The medial nucleus, which is the forward continuation of the caudal undivided gray, both in position and in cell type, is at many points scarcely separable from the midline group. Although poorly delimited this medial gray is present in reduced amounts at all levels. The ventrolateral cell mass, which is made up of neurons slightly larger than those of the midline and medial groups, extends to the front end of the nucleus. At midlevels of the hypoglossal gray a few large cells are found just ventral to the medial group. These cells, of which there are but three or four to a section, comprise the ventral division. The dorsolateral column, which is present at all but the most caudal levels of the nucleus, is made up of cells second in size only to those of the ventral nucleus. In general the configuration of the hypoglossal nucleus resembles that found by Stuurman ('16) in the mouse.

The reticular nuclei are poorly developed, the nucleus intercalatus being absent. There is a group of cells on the lateral aspect of the medial longitulinal fasciculus that may be the homologue of the nucleus of Roller. Nakamura ('30) 
found the same lack of differentiation in his Insectivora. The fiber connections of the hypoglossal nucleus followed the general pattern of the mammals.

Bat. The hypoglossal nucleus of Tadarida mexicana (fig. 18) has as simple an internal configuration as has that of any mammal. The caudal third of the nucleus is undivided. The dorsolateral column extends throughout the forward two-thirds of the nucleus on the dorsolateral aspect of the main or ventrolateral nucleus. Near the forward end of the hypoglossal nucleus a midline group appears. In a few sections there is a scattering of cells out along the hypoglossal roots which represents the ventral group. These conditions are similar to those found by Luna ('25) in Vesperugo kuhli.

The reticular gray is scarcely represented, nucleus intercalatus being but a few cells in between the hypoglossal and the dorsal vagal nucleus. Roller's nucleus is but a poorly organized mass of cells under the rostral end of the hypoglossal nucleus (fig. 18). The fiber connections of the hypoglossal nucleus are typical for mammals.

Mouse. The hypoglossal nucleus of Mus musculus (fig. 17) is divisible into a dorsal and a ventral part (Stuurman, '16). The latter is made up of four groups. The midline column is present in the middle third of the nucleus. The medial cell mass, which extends the length of the hypoglossal nucleus, has medium sized cells like those at the midline. The ventrolateral gray, a small mass of large cells, is found only in the caudal third of the nucleus. The ventral column is made up of small cells rather than the large type found in most mammals. Stuurman ('16) found its extent to be much greater than shown by the available material in which it is present only in the rostral half of the hypoglossal nucleus. The dorsal portion of the hypoglossal nucleus, consisting of a dorsomedial and a dorsolateral part, extends through the rostral fourfifths of the nucleus. In general the nuclear pattern in the available material is more complex than that described by Beccari ('22) from his material of Mus decumanus and more like that seen by Stuurman ('16) in Mus musculus (?). 

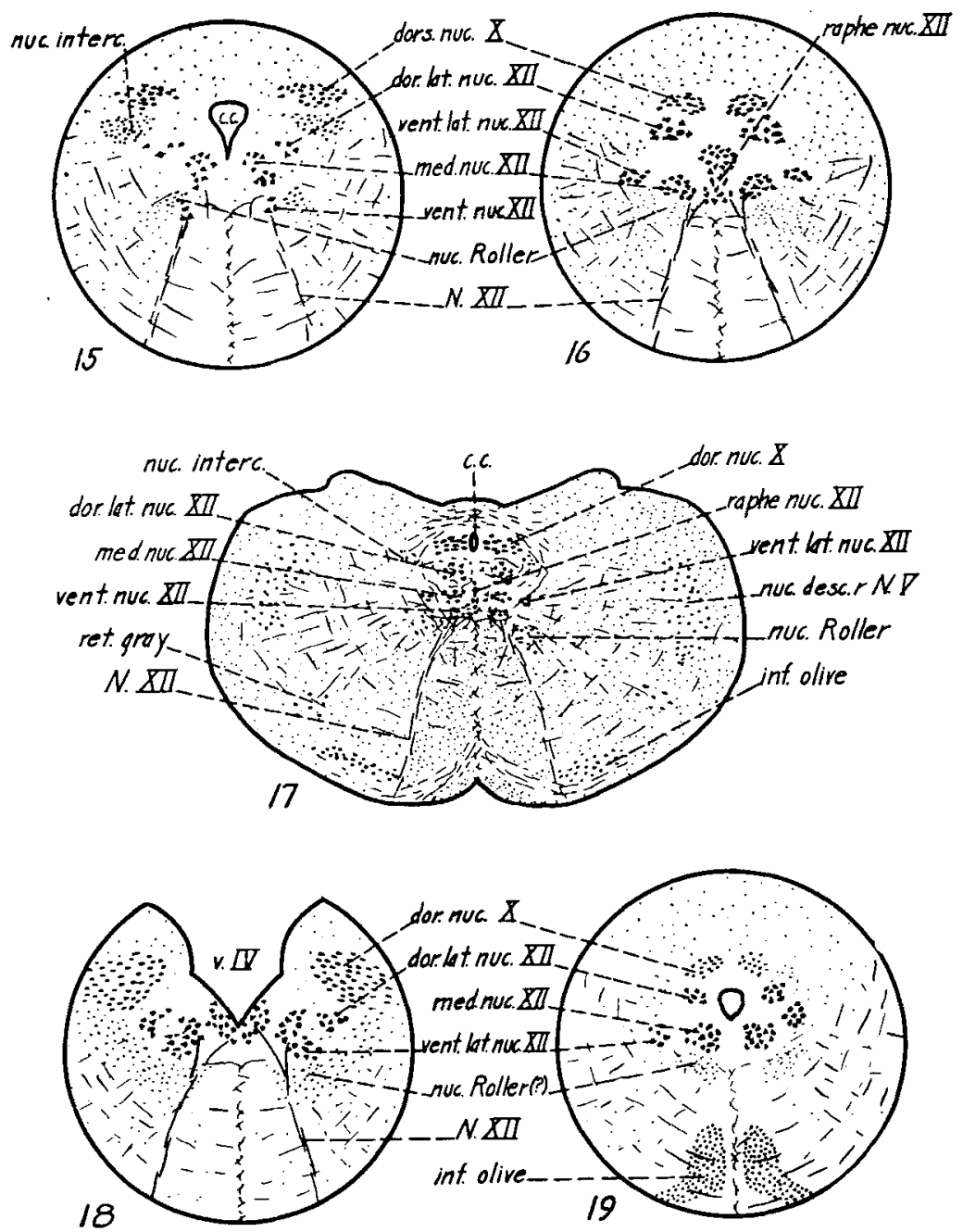

Fig. 15 Central part of a transverse section through the hypoglossal nucleus of the opossum, Didelphis virginiana. Toluidin blue. $\times 15$.

Fig. 16 Central part of a transverse section through the hypoglossal nueleus of the shrew, Blarina brevicauda. Toluidin blue. $\times 20$.

Fig. 17 A transverse section through the hypoglossal nucleus of the mouse, Mus museulus. Toluidin blue. $\times 20$.

Fig. 18 Central part of a transverse section through the hypogloseal nucleus of the bat, Tadarida mexicana. Toluidin blue. $\times 25$.

Fig. 19 Central part of a transverse section through the hypoglossal nueleus of the rat, Mus norvegicus albinus. Toluidin blue. $\times 20$. 
Reticular elements are as diffuse in the mouse as in the other lower mammals studied. A nucleus intercalatus is identified dorsolateral to the hypoglossal nucleus. Roller's nucleus may be represented by a scattered cell group ventral to the forward end of the hypoglossal nucleus and does not contribute to the hypoglossal nerve.

In whole-head silver preparations of the mouse fetus the fascicles of the hypoglossal complex may be seen collecting into three rootlets on the outside of the brain stem and leaving the cranial cavity through two foramina such that two rootlets are in the caudal and one rootlet in the cephalic foramen. In the adult mouse only one hypoglossal canal is present. In both the embryo and the adult the hypoglossal root passes to the tongue with no communication to the cervical plexus. This is similar to the situation in Didelphis marsupialis (Edgeworth, '35). Stuurman ('16) found no evidence of a ramus descendens in the mouse which is in opposition to the earlier findings of Fiendt ('14) who, on the basis of dissections, described branches to the first cervical nerve.

The fiber conections of the hypoglossal nucleus are particularly large with the lateral reticular field and with the nucleus of the descending trigeminal root. Vestibular and cerebellar fibers can be traced to the hypoglossal and the intercalate nuclei (see Allen, '27). Cortico-hypoglossal fibers are suggested in the sagittal silver material. The other connections of the hypoglossal gray are very similar to those found in other mammals.

Rat. The hypoglossal nucleus of Mus norvegicus albinus (fig. 19) is divided at caudal levels into a medial and a ventrolateral part, corresponding respectively to the alpha and gamma groups of Beccari ('22). The ventral nucleus is not present but there are occasional large cells mingled in with the cells of the ventrolateral which might represent such a ventral column. The dorsolateral part of the hypoglossal nucleus is dorsal to the ventrolateral portion and is similar to the beta group of Beccari. The reticular gray is poorly developed like that of the other lower mammals. 
The neuraxes of the hypoglossal cells leave the ventromedial angle of the nucleus to emerge from the brain stem as seven rootlets which combine into two large roots which make their exit from the skull by the way of a single hypoglossal foramen and then coalesce into a hypoglossal nerve upon which there is no ganglion. The nerve, after passing close to the vagus nerve and the cervical plexus without any exchange of fibers, proceeds alone to the suprahyoid hypobranchial musculature. The central fiber connections of the hypoglossal nucleus differ in no fundamental way from those described in other mammals.

Rabbit. In Lepus cuniculus (fig. 20) the caudal end of the hypoglossal nucleus is undivided. A short distance forward it breaks into a medial and a ventrolateral part, the former having its cells spaced farther apart than the latter. These groups persist to almost the rostral end of the hypoglossal nucleus at which level they merge into a single mass. The dorsolateral division is present in the rostral four-fifths of the nucleus becoming progressively larger at forward levels. Before terminating a dorsomedial group is split off from it.

The reticular gray is more differentiated than in any mammal this far considered. A nucleus intercalatus is present at rostral levels and grows larger until it merges with the vestibular gray. Winkler and Potter ('11) were likewise unable to find its exact forward limits. The nucleus of Roller exists at frontal levels as a round mass of cells similar to that found in higher mammals. The available material indicates that it does not contribute to the hypoglossal root.

The hypoglossal root fibers leave the brain stem and coalesce into two rootlets on each side which leave the skull through two foramina. The two roots pass the vagus nerve and then unite into a single hypoglossal nerve which goes to the tongue musculature. No connection with any other nerves is found in the available whole-head silver material. Fiendt ('14) found by dissecting that the first cervical nerve sends fibers into the hypoglossal nerve of Lepus europaeus. 
The fiber connections of the hypoglossal nucleus are similar to those found in other mammals. Winkler and Potter ('11) could find no fibers between the nucleus intercalatus and the hypoglossal nucleus. The available material has an abundance of such fibers showing.

Sheep. The caudal fifth of the hypoglossal nucleus of Ovis aries (fig. 21) is a small mass of cells which, at its forward end, splits into a medial and a ventrolateral group. The former division persists to the most rostral levels of the nucleus whereas the latter falls a little short. A third nuclear group, the ventral, is found that displaces the ventrolateral column at rostral levels. The dorsolateral nucleus is present through the forward four-fifths of the hypoglossal nucleus as a small group directly dorsal to the rest of the cell mass caudally and as a larger group lateral in position farther rostralward. At highest levels a dorsomedial nucleus is split off from it. These divisions are similar to those found by Luna ('11) in the pig.

Both the nucleus of Roller and the nucleus intercalatus are found in the available material. It is impossible to find the double nucleus of Roller spoken of by Nakamura ('30) as being present in ungulates.

Dog and Cat. The hypoglossal nuclei of the dog and cat are similar and the following account is based on dog material (fig. 22). At the level of the cephalic end of the pyramidal decussation a few scattered cells establish the continuity of the hypoglossal nucleus with the ventral horn cells of the spinal cord. The hypoglossal cells are arranged, at this caudal level, in a flattened mass, the long axis of which is pointed ventrolaterally as illustrated by Kosaka and Yagita ('03). Slightly rostral to this level the mass divides into a medial, a ventrolateral and a ventral group (fig. 22). The medial nucleus (dorsal of Pasqualino, '29), which does not extend into the frontal fifth of the hypoglossal complex, has cells which are more widely dispersed and smaller than other neurons of the nucleus. The ventrolateral division, although small rostrally, extends through the length of the hypoglossal nucleus. 
The ventral column, found only at forward levels, is made up of the largest cells of the hypoglossal nucleus. These cells, of which but a few are found in any one section, are ventral to the rest of the nucleus and at times trail out along the hypoglossal root fibers (fig. 22). The dorsolateral nucleus is in the rostral four-fifths of the hypoglossal nucleus. Throughout its forward half a dorsomedial column can be differentiated. This latter group usurps the position of the medial group as the latter becomes smaller. Ariëns Kappers, Huber and Crosby ('36) and Pasqualino ('29) have included this gray with their dorsolateral nucleus.

The reticular gray around the hypoglossal nucleus belongs mainly to either the nucleus intercalatus or the nucleus of Roller. Nucleus intercalatus is at rostral levels between the dorsal vagal nucleus and the hypoglossal nucleus much as Staderini (1896) described it. It gradually fades out on the lateral aspect of the reticular gray just ahead of the hypoglossal nucleus. The nucleus of Roller lies ventral to the forward half of the hypoglossal nucleus and just lateral to the ventrally running hypoglossal root fibers. In transverse cell material the nucleus is circular in appearance with the long axes of the cells parallel to the circumference of the circle. In the available Cajal and Weigert material no evidence is found that Roller's nucleus contributes to the hypoglossal nerve. Other reticular gray around the hypoglossal nucleus are the nucleus funiculus teretis, the anterolateral (or accessory) nucleus of Duval (1876) and Koch (1888) and the nucleus funiculi anteriores of Obersteiner ('00). The first of these is but poorly represented in the dog but what there is of it is in the same position as that given to it by Marburg ('04). The anterolateral nucleus of Duval is probably part of the same group called nucleus reticularis diffusus by von Kölliker (1896). The cells of this poorly defined group are along the hypoglossal root fibers. The anterior funicular nucleus is in the substance of the medial longitudinal fasciculus, in relations similar to those described for man. 
The root fibers leave the ventromedial angle of the nucleus to pass down along the lateral aspect of the medial longitudinal fasciculus. After cutting through the lateral part of the inferior olive they leave the brain stem in several rootlets which coalesce into a single hypoglossal nerve.

The fiber connections of the hypoglossal nucleus of the dog are similar to those of other mammals. There are considerable contributions from the lateral reticular gray and the nucleus of the descending trigeminal root. The nucleus of fasciculus solitarius sends neuraxes directly to the bypoglossal gray. Vestibular fibers reach the nucleus as internal arcuates as well as by way of the rostral end of nucleus intercalatus. Fibers from the medial longitudinal fasciculus are made up of cortico-bulbars (Hoche, 1898) and internuclears. The reticular connections are greater at caudal levels whereas those from the nucleus of the fasciculus solitarius are better developed at higher levels. Numerous hypoglossal dendrites extend out toward the descending systems of the lateral field. The dorsal longitudinal fasciculus sends fibers into the hypoglossal gray but no trace of Nakamura's ('30) connection to the nucleus of Roller is found.

Monkey. In Macacus rhesus the hypoglossal nucleus (fig. 23 ), in front of a short caudal undifferentiated end, is divided into a medial, a ventrolateral and a ventral part. The medial column (fig. 23), which is close to the midline, is characterized by relatively large intercellular spaces. The ventrolateral portion is directly continuous with the caudal end of the hypoglossal nucleus both in position and in cell type. The ventral division is found at middle levels of the nucleus as a small group of large cells. The dorsolateral column, which is present only in the rostral four-fifths of the hypoglossal gray, is made up of large cells which approach those of the ventral nucleus in size. At many levels there is a splitting of this column into a medial and a lateral part, the former being the dorsomedial nucleus.

The reticular gray around the hypoglossal nucleus is similar to that in man but more poorly differentiated. Nucleus 

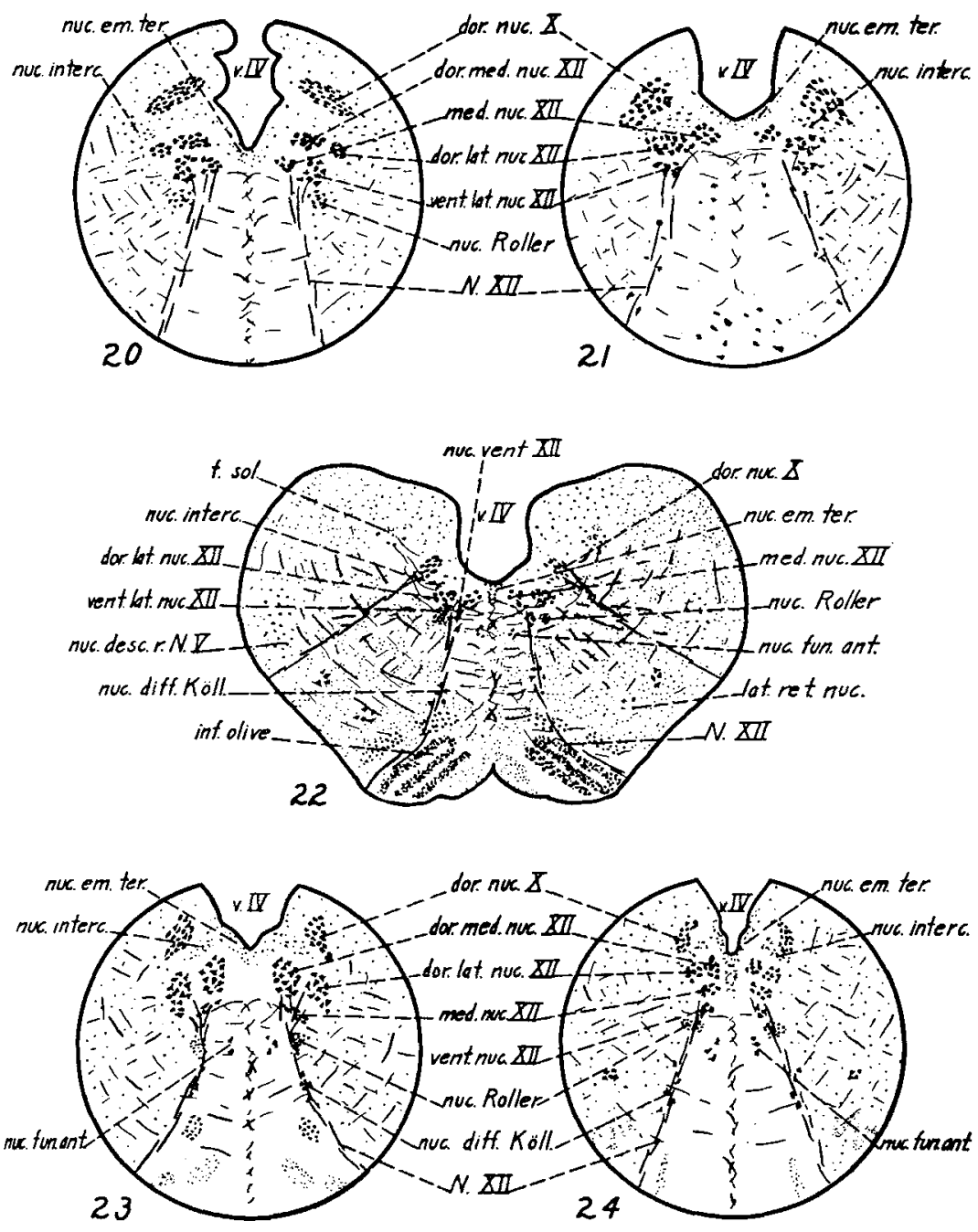

Fig. 20 Central part of a transverse section through the hypoglossal nucleus of the rabbit, Lepus cuniculus. $\times 15$.

Fig. 21 Central part of a transverse section through the hypoglossal nueleus of the sheep, Ovis aries. Toluidin blue. $\times 10$.

Fig. $22 \mathrm{~A}$ transverse section through the hypogiossal nucleus of the $\mathrm{dog}$. Toluidin blue. $\times 15$.

Fig. 23 Central part of a transverse section through the hypoglossal nueleus of the monkey, Macacus rhesus. Toluidin blue. $\times 10$.

Fig. 24 Central part of a transverse section through the hypoglossal nucleus of man. Toluidin blue. $\times 10$. 
intercalatus (fig. 23) is represented at all but the most caudal levels of the hypoglossal nucleus. Farther forward it is run in with the nucleus praepositus, this latter being more or less continuous with the medial vestibular nucleus. Roller's nucleus lies at rostral levels and at the tip of the hypogossal nucleus is continuous with the nucleus praepositus. The nucleus eminentia teretis is best developed at forward levels as it lies on the medial and the dorsal aspects of the hypoglossal nucleus. Near the highest levels of the latter it has a midline condensation which runs in with the raphe nucleus ventrally.

The root fiber and the fiber connections of the hypoglossal nucleus are similar to those of the higher mammals. The description relating to the $\mathrm{dog}$ is not essentially different from conditions found here.

Man. As early as 1865 Deiters illustrated subdivisions within the hypoglossal nucleus but did not label them. Ziehen ('03) divided the nucleus into a dorsomedial, a dorsolateral and a ventral column. Parhon and his colleagues ('00, '03, '04, '05) spoke of an internal, an external, a central and an anterior group. Hudovernig ('07) and Goldstein and Minea ('09) found a similar pattern. Ariëns Kappers, Huber and Crosby ('36) found a grouping similar to that of Ziehen. Pearson ('39) has studied the embryology of the nuclear groups in man.

The hypoglossal nucleus of the available material may be divided into a ventrolateral, a ventral, a dorsolateral and a dorsomedial group (fig. 24). The medial nucleus is large and close to the midline, corresponding in position to the dorsomedial nucleus of Ziehen, to the medial nucleus of Ariëns Kappers, Huber and Crosby, and to the internal nuclens of Parhon, Hudovernig and Goldstein and Minea. This medial gray, which is characterized by the large spaces between the cells, is made up of cells that stain lightly and are somewhat smaller than those of other groups of the hypoglossal nucleus. The nucleus extends almost the entire length of the hypoglossal complex, becoming larger at rostral levels near its termination. The part of the hypoglossal nucleus designated 
here as the ventrolateral division corresponds to the central or ventral group of other authors. Its cells are closer together and somewhat larger than those of the medial group. They extend through the caudal two-thirds of the hypoglossal nucleus, their space being occupied rostrally (fig. 24) by a further splitting of the dorsolateral column into a dorsomedial and a dorsolateral part. On the ventromedial aspect of the ventrolateral group the ventral division is found. These cells, which are outstanding because of their great size, can be followed out along the hypoglossal root fibers for short distances. Most observers have considered them as a part of their larger ventral division, a notable exception being Parhon who called them the anterior group.

The dorsolateral nucleus has received the same name from Ziehen ('03) and Ariëns Kappers, Huber and Crosby ('36), but other workers have called it the dorsal, lateral or external group. The dorsolateral column, which extends through the rostral four-fifths of the hypoglossal nucleus, shifts to a more ventral position at forward levels such that it occupies the area which more caudally was taken by the ventrolateral group. It alone forms the most rostral tip of the hypoglossal nucleus.

Roller in 1881, using Weigert material, located a smallcelled group on the ventral aspect of the rostral half of the nucleus which he believed contributes to the hypoglossal nerve. This group is clearly seen in the available material in much the same relations as described for it by Ramón y Cajal ('09). As pointed out by Lieberson ('35) it has a medial and a lateral part at many levels. This feature is probably no more than a splitting of the nucleus by the ventrally running hypoglossal root fibers. Mingazzini ('28) found degeneration in the nucleus of Roller after cutting the hypoglossal nerve whereas Staderini (1895), Kosaka and Yagita ('03), Parhon and Nadejge ('05), Hudovernig ('07) and Lieberson ('35) found none after the same procedure. Ziehen ('03) and Vincenzi (1884) and Ramón y Cajal ('09), using Golgi preparations, found no neuraxes of the impregnated cells of Roller's 
nucleus entering the hypoglossal root. They were of the opinion that the nucleus was reticular in nature and subservient to the function of the hypoglossal nucleus. In general, those workers who have allowed the possibility that Roller's nucleus contributes to the hypoglossal nerve have used hematoxylin material of one sort or another. Among these observers may be mentioned Roller (1881), Edinger ('08), Jacobson ('09), Berkelbach van der Sprenkel ('24), Wilson ('33) and Goldin ('34). Others who used the same type of material but who did not believe that Roller's nucleus contributes to the hypoglossal nerve are Vincenzi (1884), Koch (1888), Kölliker (1896), and Obersteiner ('00). Experimental results (excepting those of Mingazzini) and Golgi material have pointed to the reticular nature of the nucleus of Roller. The available material, silver and experimental, is in agreement with this last opinion.

The nucleus intercalatus of Staderini (1896) is found on the lateral aspect of the rostral portion of the hypoglossal nucleus separating it from the dorsal vagal nucleus. Rostralward the nucleus intercalatus is continuous with the nucleus praepositus and dorsomedially it runs into the nucleus funiculi teretis. Caudalward the intercalate gray becomes less marked and at the obex is indistinguishable from the surrounding gray. Nucleus eminentia teretis is less well-defined than the other hypoglossal reticular nuclei. Its cells, which are smaller than those of the other reticular gray masses, are present at all levels where the hypoglossal nucleus underlies the open floor of the fourth ventricle. The anteroexternal or accessory nucleus of Duval was believed by Duval (1876), Koch (1888), Mingazzini ('28) and Goldin ('34) to contribute to the hypoglossal nerve. Ramón y Cajal ('09) and Lieberson ('35) denied this. In the available material there are cells among the outgoing hypoglossal rootlets as these latter pass toward the hilus of the inferior olive but they appear similar to neurons of the olivary complex rather than as cells of the efferent type. The nucleus reticularis diffusus of Kölliker (1896) is made up of large cells scattered out along the hypoglossal root. Some workers have confused this nucleus with 
the anteroexternal group of Duval, which has a more ventral position.

\section{MUSCULAR LOCALIZATION}

The earliest observations on muscular localizations within the hypoglossal nucleus of mammals were those of Parhon and Goldstein ('00). These pioneer results, which are somewhat vague and open to criticism, were obtained from autopsy material of tumors of the tongue and of the floor of the mouth. The conclusions reached were that: (1) the hyoglossal and styloglossal muscles are innervated by anteriorly (?) placed cells, (2) the superior lingual and amygdaloglossal muscles by external cells, (3) the infrahyoid musculature via the ramus descendens hypoglossi from inferior cells, and (4) the inferior lingual and styloglossal muscles by the rest of the hypoglossal nucleus. Parhon and Parhon ('03) reported a case in which the external cells supplied the superior and lateral portions of the tongue, i.e., the pharyngoglossal, amygdaloglossal and palatoglossal muscles. Parhon and Papinian ('04) verified this latter study and added that the geniohyoid muscle is supplied by a small group of large cells ventrally placed. Likewise they restricted the source of the ramus descendens hypoglossi to the dorsolateral portion of the caudal end of the hypoglossal nucleus. However, their paper leaves something to be desired since they localized the innervation of the mylohyoid muscle in the hypoglossal nucleus. Parhon and Nadejge ('05) simply verified a few of the earlier observations concerning the innervation of the dorsolateral aspect of the tongue and of the geniohyoid muscle. Kosaka and Yagita ('03), in experimental work on dogs, found that the ramus descendens hypoglossi comes from the dorsolateral part of the caudal hypoglossal nucleus, that the branches to the geniohyoid muscle arise from the large, ventrally placed cells, that the cells which innervate the hyoglossal muscle are in the dorsolateral part of the hypoglossal nucleus at all levels except the most caudal, that the anterior two-thirds of the tongue is supplied by cells near the midline, and that the 
genioglossal muscle receives innervation from cells which are intermediate in position. These workers did not, however, analyze their findings in terms of the natural subgroupings of the hypoglossal nucleus. Hudovernig ('07), with pathological, human material, arrived at the same general localizations as Parhon and his colleagues. Goldstein and Minea ('09) found muscular localizations within the hypoglossal nucleus that are at variance with most other work, notably that the cells which innervate the geniohyoid muscle are dorsally placed. Their material gave no evidence that the ramus descendens hypoglossi arises from the hypoglossal nucleus. Stuurman ('16) did experimental work on the muscular localizations within the hypoglossal nucleus of the mouse. In this nucleus, which, in the mouse, is differently arranged from that of carnivores or primates, Stuurman found the cells for the hyo- and styloglossal muscles located dorsally, those for the intrinsic muscles intermediate in position and those for the genioglossal and geniohyoid muscles ventrally. Berkelbach van der Sprenkel ('24) traced the hypoglossal fibers from the cell bodies to muscle fibers in an hematoxylin-eosin series of a $17.5 \mathrm{~mm}$. hedgehog embryo. His localization pattern is quite different from that of other investigators working on other forms, this latter fact most probably being an expression of the early age of his specimen as well as of species differences.

The present work has attempted to repeat and extend some of the experimental work done on the dog by Kosaka and Yagita and to define the results in terms of the natural groupings within the hypoglossal nucleus. For this purpose ten dogs were anesthetized and operated on under sterile conditions. Following a longitudinal incision on the ventral surface of the neck, the hypoglossal nerve was identified as it ran under the caudal border of the mylohyoid muscle. After cutting this latter muscle it was easy to lay out all of the branches which go to the tongue musculature. The nerves cut in the various operations were as follows: $\operatorname{dog} 1$, XII distal to the ramus descendens hypoglossi; $\operatorname{dog} 2$, branches to the geniohyoid muscle; $\operatorname{dog} 3$, branches to the hyo- and 
styloglossal muscles; $\operatorname{dog} 4$, branches to the hyo- and styloglossal muscles; $\operatorname{dog} 5$, branches to the hyoglossal muscle; dog 6 , branches to the styloglossal muscle; $\operatorname{dog} 7$, branches to the intrinsic and genioglossal muscles; $\operatorname{dog} 8$, branches to the intrinsic and genioglossal muscles; $\operatorname{dog} 9$, ramus descendens hypoglossi; dog 10, ramus descendens hypoglossi.

The animals were killed after a period of 16 to 21 days following the operation. The brain stems were placed in $\mathrm{Hu}-$ ber's ('27) trichloracetic acid fixative and the tongues in $10 \%$ formalin. Serial sections were made of the brain stem and stained with toluidin blue. Sample transverse sections were made of various levels of the tongue and stained in hematoxylin and eosin.

In study of the brain stem sections typical chromatolysis is found in the hypoglossal nucleus. The affected cells have an eccentrically placed nucleus, diminution of Nissl substance, and a tendency to a swollen or rounded appearance. The time element in the reactions of the individual cells is such that all of the cells do not show the same degree of pathology at the same time and as a consequence no more than a few of these changed cells are found in any one section.

The transversely cut tongue sections reveal the effects of cutting the nerve branches. Using the tongue muscle of the opposite side as the normal control it is possible to check that the operation was performed on the proper muscular branches by the smaller size of the denervated muscle as a whole and of the muscle fibers individually. The size differences are more apparent in those animals killed after 21 days than in those killed after 16 or 17 days.

Chromatolysis, when found, is always in the chief nucleus of the same side as that on which the operation was performed. Examination of all the surrounding reticular groups such as the nucleus intercalatus and the nucleus of Roller shows no change from the normal following operation.

Dog 1 , in which the hypoglossal nerve was cut distal to the ramus descendens hypoglossi, has chromatolysis scattered throughout all the groups of the nucleus of the affected side. 
Dog 2, in which the geniohyoid nerve supply was cut, shows pathological changes only in the ventral nucleus.

Dogs 3 and 4, in which the nerve supply to the hyoglossal, superior longitudinal, and styloglossal muscles was cut, show chromatolysis in the dorsolateral and in the dorsomedial groups.

Dog 5 , in which the branches to the hyoglossal muscle were cut, has chromatolysis in the dorsolateral nucleus.

Dog 6, in which the nerve supply to the styloglossal was cut, has pathology in both the dorsolateral and dorsomedial columns.

Dogs 7 and 8, in which the anterior end of the hypoglossal nerve to the intrinsic (transverse and vertical) and genioglossal muscles was cut, have chromatolytic changes in the medial and ventrolateral divisions.

Dogs 9 and 10, in which the ramus descendens hypoglossi was cut, show chromatolysis in the dorsolateral column at its caudal end.

The conclusions from the foregoing may be summarized as follows :

ventral nucleus

dorsolateral nucleus (caudal)

dorsolateral nucleus (rostral three-quarters)

dorsomedial nucleus

medial nucleus

ventrolateral nucleus geniohyoid muscle

part of infrahyoid museulature via the ramus descendens hypoglossi

hypoglossal and styloglossal muscles

styloglossal musele

$\{$ transverse and vertical muscles

$\{$ genioglossal muscle

The work of Kosaka and Yagita ('03) indicated that the medial nucleus is specifically for the transverse and vertical, intrinsic muscles whereas the ventrolateral nucleus is related to the genioglossal muscle.

The experimental results agree rather closely with those of many earlier workers. The work of Kosaka and Yagita ('03) on the dog confirms these data in many respects and disagrees in none. In the mouse, Stuurman ('16) obtained similar findings when the species differences are considered. Parhon and 
his colleagues ('00, '03, '04, '05) found essentially the same localizations in man as has been given for the dog.

Embryologically the tongue musculature differentiates from a common primordium (Edgeworth, '35) into three main masses which give rise respectively to (1) the geniohyoid muscle, (2) the genioglossal muscle, from which develop the transverse and vertical intrinsic muscles, and (3) the hyoglossal muscle, from which the styloglossal and superior longitudinal muscles split off.

The branches of the peripheral hypoglossal nerve also suggest the above grouping into three units, there being a set of filaments for each of them. There is a nerve to the geniohyoid muscle, a closely interrelated set of branches to the hyo- and styloglossal muscles and the terminal ends which go to the genioglossal, transverse and vertical muscles.

Centrally, the close proximity of the dorsolateral and dorsomedial columns (fig. 22), as well as the relative agreement of their cells as to size and to dispersion (p. 507), points to the similarity of the peripheral muscles innervated. In the same manner the medial and ventrolateral divisions, which send their neuraxes to transverse and vertical intrinsic muscles and to the genioglossal muscle respectively are very closely related centrally. The ventral nucleus, fibers of which distribute to the geniohyoid muscle, is like the muscle which it innervates, set apart from its fellows.

\section{DISCUSSION}

The comparatively simple hypoglossal nucleus of the frog has only a suggestion of dorsal and ventral subdivisions. This lack of differentiation is in keeping with the relatively stereotyped activity of the frog tongue. The intimate relation of the hypoglossal cells to the anterior horn column of the spinal cord betrays their phylogenetic descent from it.

Reptiles show but little greater complexity in the organization of the hypoglossal nucleus. Differences between the various reptiles are found but cannot, as yet at least, be associated with specific differences in the tongue and its activity but 
rather appear to be reflections of the general level of organization of the nervous system of the particular reptile in question. Thus chelonians have a simpler hypoglossal nucleus than does the alligator whereas the alligator has the simpler and less active tongue.

The hypoglossal nucleus of birds shows a great advance in specialization over that of reptiles. The outstanding feature is the clear division of the nucleus into a dorsal and a ventral portion. Whether or not the development of the syrinx plays an important part in this greater complexity is not settled although Edgeworth ('35) is of the opinion that the syrinx is innervated by the vagus and the cervical nerves. In this connection it is noteworthy that the largest and most complex hypoglossal nucleus found in the available bird material is in the parrakeet, a bird with a large fleshy tongue and only a moderately developed syrinx. A true nucleus intermedius is not found in the forms studied. If the nucleus intermedius contains both vagal and hypoglossal neurons it should be possible to tell them apart in Nissl preparations, because of the differences in the cells of the two columns. In all of the available material the cells of the hypoglossal nucleus are of the somatic efferent type.

The hypoglossal nucleus of mammals is more completely emancipated from the spinal cord in a spatial sense than that of lower forms. However, the significance of this greater separation is obscured by the greater number of ascending and descending systems between the spinal cord and higher centers and in particular by the decussation of the corticospinal tract which takes place between the cephalic end of the anterior horn column and the caudal end of the hypoglossal nucleus.

Generally about five subdivisions are found in the mammalian hypoglossal nucleus. These are: (1) a medial group near or on the midline, (2) a ventrolateral column extending laterally from the medial group, (3) a small ventrally situated patch of cells which in some instances run out along the root fibers, (4) a dorsolateral nucleus, and (5) a dorsomedial 
nucleus which is usually fused with the last mentioned group. The names used suggest a homology of the divisions throughout mammals which is by no means certain. There are factors, such as the size and compactness of the cells, which, aside from the positional similarities, lend credence to the homologies but only extensive experimental work could prove that supposed homologues innervated corresponding muscles. The lengths of the various subgroups are in a general way alike from form to form. Each of the subdivisions innervates a more or less discrete peripheral unit of muscle. The muscles which receive their innervation from a single nucleus are anatomically and physiologically related in the periphery.

The hypoglossal nucleus of vertebrates above tailed amphibians is a portion of the anterior horn column that finds itself functionally more closely related to the brain stem than to the spinal cord. The tongue must cooperate with the muscles of mastication both in prehension and in mastication, with the musculature of the pharynx in the act of swallowing (Negus, '31), and in mammals with the facial muscles around the mouth. In addition to this motor coordination the tongue has its sensory supply from three or four cranial nerves other than itself and must act according to their stimulation. In all, the hypoglossal nucleus is part of a cranial nerve functionally. The importance of taste has been overemphasized by some authors, it appearing likely that vision, olfaction and tactile are greater factors in the grasping and handling of objects by the tongue of most mammals.

The fiber connections of the hypoglossal nucleus bear out the functional postulates of tongue activity. Ramón y Cajal ('09) has illustrated the relations of secondary trigeminal, vagal and glossopharyngeal connections to the, hypoglossal nucleus in mammals. No significant differences in the fiber connections among the various vertebrates are found other than the general lack of complexity and volume in lower forms as compared to higher animals. There are always strong internuclear connections across the midline. In lower vertebrates the dendrites pass out laterally to the reticular gray 
and the nucleus of the descending trigeminal root as well as incoming axons from these regions; the latter are much increased in higher forms. Visceral gray along the fasciculus solitarius contributes fibers to the hypoglossal nucleus and to the surrounding reticular gray such as nucleus intercalatus. The medial longitudinal fasciculus sends fibers into the hypoglossal nucleus of all forms.

The neuraxes of the hypoglossal cells all appear to be uncrossed fibers from the chief nucleus, it not being possible to trace any of them from the nucleus of Roller even in the experimental series. The root fascicles coalesce into hypglossal rootlets after leaving the medulla oblongata, there being from one to three of them in the forms studied. These roots eventually join on leaving the skull to form the hypoglossal nerve, which passes to the suprahyoid, hypobranchial musculature and in but one instance (dog), where the peripheral distribution is studied, is it possible to find hypoglossal twigs to the infrahyoid muscles.

The reticular nuclei of the hypoglossal nucleus, which in the higher forms are the nucleus intercalatus, the nucleus funiculus teretis, the nucleus of Roller and the nucleus praepositus, all appear to be specializations of the general reticular gray such as is found in the frog. In the phylogenetic ascent they differentiate one by one so that they appear to serve the increasing complexity in structure and connections of the hypoglossal nucleus. The present state of knowledge indicates that they are subservient in a general rather than in a specific way. Nucleus intercalatus serves as a case in point. Ariëns Kappers and others have thought of it as receiving visceral fibers, Allen has described cerebellar connections, and Luna ('10) has emphasized its fiber relations with the lateral reticular gray.

Nothing concerning the proprioceptive fibers from the tongue can be offered other than negative evidence. No sensory endings in the tongue of the 6-day-old rabbit are found in several excellent silver series although they can be identified in the neck muscles of these specimens. For recent work on the 
proprioceptive innervation of the tongue the contributions of Yee, Harrison and Corbin ('39) and Carleton ('38) should be consulted.

\section{SUMMARY}

1. The hypoglossal nucleus, its root fibers and its secondary connections are described in the frog and in certain reptiles, birds and mammals.

2. Subgroups within the hypoglossal nucleus are named and described for all forms in which they are found.

3. A tentative homology is suggested for all of the subgroups in the hypoglossal nucleus of mammals. These are indicated by the terminology which gives to each mammal a medial, a ventral, a ventrolateral, and a dorsolateral group.

4. Experimentally obtained muscular localizations in the dog suggest which of the subdivisions innervate the various muscle units of the tongue.

5. The reticluar nuclei around the hypoglossal nucleus are described.

\section{LITERATURE CITED}

AdDens, J. L. 1933 The motor nuclei and roots of the eranial and first spinal nerves of vertebrates. Zeits. f. Anat. u. Entwicklungsgesch., I. Abt. Zeits. f. ges. Anat., Bd. 101, S. 307-410.

1934 A critical review of the occurence of crossing root fibers in facialis, vestibular, glossopharyngeal and vagus nerves. Psychiat. en neurol. Bl., pp. 274-283.

ALLEN, W. F. 1927 Experimental-anatomical studies on the visceral bulbospinal pathway in the cat and guinea-pig. J. Comp. Neur., vol. 42, pp. 393456.

ARIËNS KAPPERS, C. U. 1911 Weitere Mitteilungen über Neurobiotaxis. VI. The migrations of the motor root-cells of the vagus group and the phylogenetic differentiation of the hypoglossus nucleus from the spinooccipital system. Psychiat. en neurol. Bl., vol. 15, pp. 408-427.

1912 Idem. VII. Die phylogenetische Entwicklung der motorisehen Wurzelkerne in Oblongata und Mittelhirn. Folia Neuro-biol., Bd. 6, Sommer-Ergänzungs-Heft, S. 1-142.

1920 Vergleichende Anatomie des Nervensystems. Haarlem, E. F. Bohn.

ARIËNS KAPPERS, C. U., G. C. HubER AND E. C. CROSBy 1936 The comparative anatomy of the nervous system of vertebrates including man. New York, MacMillan \& Co. 
BARNARD, J. W. 1936 A phylogenetic study of the visceral afferent areas associated with the facial, glossopharyngeal and vagus nerves and their fiber connections. The efferent facial nucleus. J. Comp. Neur., vol. 65, pp. 503-602.

1937 The mammalian hypoglossal nucleus. Univ. Hosp. Bull., Univ. of Michigan, vol. 3, pp. $41-42$.

Beccari, N. 1922 Studi comparativi sulla struttura del rombencefalo. I. Nervi spino-occipiptali e nervo ipoglosso. II. Centri tegmentali. Arch. ital. di Anat. e di Emb., vol. 19, pp. 122-291.

Berkelabach vaN der SPREnKel, H. 1924 The hypoglossal nerve in an embryo of Erinaceus europaeus. J. Comp. Neur., vol. 36, pp. 219-272.

BLACK, D. 1917 The motor nuclei of the cerebral nerves in phylogeny: A study of the phenmomenon of neurobiotaxis. II. Amphibia. J. Comp. Neur., vol. 28 , pp. $379-424$.

- 1922 Idem. IV. Aves. J. Comp. Neur., vol. 34, pp. 233-275.

Brandis, F. 1893 Untersuehungen über das Gehirn der Vögel. II. Theil: Ursprung der Nerven der Medulla oblongata. Arch. f. mikr. Anat., Bd. 41 , S. $623-649$.

Charleton, A. 1938 Observations on the problem of the proprioceptive innervation of the tongue. J. Anat., vol. 72, pp. 502-512.

DErTFRs, O. 1865 Untersuchungen über Gehirn und Rückenmark des Menschen und der Säugethiere. Braunschweig, F. Vieweg and Sohn.

DrBors, F. S. 1929 The tractus solitarius and attendant nuclei in the Virginian opossum (Didelphis virginiana). J. Comp. Neur., vol. 47, pp. 189224.

Duval, M. 1876 Recherches sur l'origine réelle des nerfs craniens. J. de l'anat. et de la physiol., pp. 496-524.

EDgfworth, F. H. 1935 The eranial muscles of vertebrates. Cambridge University Press.

Edinger, L. 1908 Vorlesungen über den Bau der nervosen Centralorgane des Menschen und der Thiere. Leipzig, F. C. W. Vogel.

Finndt, E. 1914 Ueber das Wurzelgebiet des Nervus hypoglossus und den Plexus hypoglosso-cervicalis bei den Säugetieren. Morph. Jałrb., Bd. 48, $513-643$.

Fürbringerr, M. 1897 Ueber die spino-occipitalen Nerven der Salachier und Holocephalen und ihre vergleichende Morphologie. Festschr. f. Gegenbaur, Bd. 3, S. 349-788.

GaupP, E. 1899 Anatomie des Frosches. Ecker, Wiedersheim and Gaupp, Braunschweig, F. Vieweg u. Sohn.

Gehuchten, A. vas 1897 Anatomie du système nerveux de I'homme. Louvain, A. Uystpruyst-Dieudonne.

Goldis, L. 1934 Zur Frage der Zusammensetzung des Hypoglossuskemes und über die Zellengrouppen, die mit geinen Wurzeln topographisch Zusammenhangen. Anat. Anz., Bd. 78, S. 81-89.

Golostrin, M., AND L. Minea 1909 Quelques localisations dans le noyau de 1 'hypoglosse et du trijimineau chez l'homme. Folia Neuro-biol., Bd. 3. S. $135-151$. 
Hocke, A. 1898 Beiträge zur Anatomie der Pyramidenbahn und der oberen Schleife nebst Bermerkungen über die abnormen Bündel in Pons und Medulla oblongata. Arch. t. Psychiat. u. Nervenkr. Berl., Bd. 30, S. $103-136$.

HUBER, G. C. 1927 New method of fixation and staining of the central nervous system, for purpose of study of cytoarchitecture. Contributions to Medical Science, Aldred Scott Warthin anniversary volume, pp. 1-12, Ann Arbor, Wahr.

Hudovernia, C. 1907 Beiträge zur mikroskopisehen Anatomie und zur Localisationslehre einiger Gehirnnervenkerne. J. f. Psychol. u. Neur., Bd. 9, S. 137-164.

JACOBson, L. 1909 Ueber die Kerne des menschlichen Hirnstammes. Neur. Centralbl., Bd. 28, S. 674-679.

KIMMEL, D. L. 1940 Differentiation of the bulbar motor nuclei and the coincident development of associated root fibers in the rabbit. J. Comp. Neur., vol. 72, pp. 83-148.

Косн, P. D. 1888 Untersuchungen über den Ursprung und die Verbindungen des Nervus hypoglossus in der Medulla oblongata. Areh. f. mikr. Anat., Bd. 31, .S. 54-71.

KöldIKer, A. voN 1896 Handbuch der Gewebellehre des Menschen. Bd. II., Leipzig, W. Engelman.

Kosaka, K., AND K. Yagita 1903 Experimentelle Untersuchungen über die Ursprung des Nervus hypoglossus und seines absteigenden Astes. Jahrb. f. Psychiat. u. Neur., Bd. 24, S. 150-189.

Limberson, G. 1935 Zur Frage über den Bau einiger motorisches Hirnnerven. Anat. Anz., Bd. 79, S. 401-417.

Luna, E. 1910 Zur Morphologie und zur Entwicklung des Nucleus intercalatus (Staderini). Folia Neuro-biol., Bd. 4, S. 242-253.

1911 Ricerche istologiche, istogeniche, e morfogenetiche sul nucleo dell' ipoglosso. Ricerche fatte nel Lab. di Anat. normale della R. Univ. di Roma ed in altri Lab. biol., vol. 16, pp. 1-25.

1925 Nuclei dei nervi encefalici e loro connessioni nei Chirotteri. I. Il nervo ipoglosso. Arch. ital. anat. e embriol., vol. 22, pp. 1-34.

MARBURG, O. 1904 Mikroscopisch-topographischen Atlas des menschlichen Zentral nervensystems. Leipzig u. Wien, F. Deuticke.

Mingazzini, G. 1928 Möllendorff-Handbuch der mikroskopischen Anatomie des Menschen. Bd. 4, Abt. I.

Nakamura, T. 1930 Der Rollersche Kern. Arbeit. aus den neur. Inst. der Wiener Univ., Bd. 32, S. 61-94.

Obersteiner, H. 1900 Anatomy of the central nervous organs. London, Ch. Griffin and Co.

NeGUS, V. E. 1931 The mechanism of the Iarynx. New York, G. V. Mosby Co.

Parhon, C., and M. Goldstein 1900 Lésions sécondaires dans le cellules du noyau de l'hypoglosse a la suite d'un cancer de la langue. Considerations sur la morphologie de ce noyau chez l'homme. Eassais de localisations. Rom. Med., vol. 8, pp. 36-37.

PARHON, C., AND G. NADEJGE 1905 Nouvelle contribution à l'étude des localisations dans les noyaux nerfs craniens et rachidens chez l'homme et chez le chein. Rev. Neur., vol 13, pp. 851-852. 
Parhon, C., and J. Papinian 1904 Contribution à l'étude des localisations dans les noyaux bulbo-protubérantiels (hypoglossal et facial) chez l'homme. Sem. Med., vol. 24, pp. 401-403.

Parhon, C., and C. Parhon 1903 Contribution à l'étude des localisations dans le noyau de l'hypoglosse. Rev. Neur., vol. 11, pp. 461-463.

Pasqualino, G. 1929 Il nucleo del nervo ipoglosso nel cane. Ricerche di Morfologia, vol. 9, pp. 229-243.

Pearson, A. A. 1939 The hypoglossal nerve in human embryos. J. Comp. Neur. rol. 71 , pp. 21-39.

RAMón y CAJAL, S. 1909 Histologie du systéme nerveux de l'homme et des vertébrés. Paris, A. Maloine.

ROLLER, F. C. W. 1881 Ein kleinzelligen Hypoglossuskerne. Areh. f. mikr. Anat., Bd. 19, S. 383-396.

SANDERS, E. B. 1929 A consideration of certain bulbar, midbrain, and cerebellar centers and fibers tracts in birds. J. Comp. Neur., vol. 49, pp. $155-222$.

StADERINI, R. 1895 Rieerche sperimentali sopra la origini reale del nervo ipoglosso. Intern. Monatsehr. f. Anat. u. Physiol., Bd. 12, S. 220-246. 1896 Ubicazione e rapporti di alcuni nuclei di sostanza grigia della midolla allungato. Intern. Monatsehr. f. Anat. u. Physiol., Bd. 13, S. 326-355.

StuUrman, F. J. 1916 Die Localization der Zungenmuskeln in Nucleus hypoglossi. Anat. Anz., Bd. 48, S. 593-610.

1916a Der Hypoglossuskern von Ameisenfresser. Anat. Anz., Bd. 49 , S. $342-348$.

TuaE, H. 1932 Somatic motor mechanisms in the midbrain and medulla oblongata of Chrysemys elegans (Wied.). J. Comp. Neur., vol. 55, pp. $185-271$.

VINCEnZI, L. 1884 Sur l'origine réelle de quelques nerfs cérébraux. Arch. ital. de Biol., vol. 5, pp. 109-130.

1903 Sulla presenza di fibre incrociate nervo ipoglosso. Anat. Anz., vol. 22 , pp. $567-568$.

VöLKER, C. 1908 Quoted from Edgeworth, 1935.

VoRIs, H. C., AND N. L. HOERR 1932 The hindbrain of the opossum, Didelphis virginiana. J. Comp. Neur., vol. 54, pp. 277-355.

WILlard, W. A. 1915 The cranial nerves of Anolis carolinensis. Bulletin of the Museum of Comparative Biology of Harvard, vol. 59, pp 15-116.

Wilson, R. B. 1933 The anatomy of the brain of the whale (Balaenoptera sulfurea). J. Comp. Neur., vol. 58, pp. 419-480.

WinkLer, C., AND A. Porter 1911 An anatomical guide to experimental researches on the rabbit's brain. Amsterdam, Versluys.

YEE, J., F. HARRIson, ANd K. B. Corbin 1939 The sensory innervation of the spinal accessory and tongue musculature of the rabbit. J. Comp. Neur., vol. 70, pp. 305-325.

ZIEHEN, T. 1903 Handbuch der Anatomie des Mensehen by Bardeleben. Bd. 4, Jena, G. Fiseher. 